\title{
ANÁLISE MORFOTECTÔNICA DO PLANALTO DO JUQUERIQUERÊ, SÃO SEBASTIÃO*
}

\author{
GINALDO A.C. CAMPANHA**, HENDRIK H. ENS** e WALDIR L. PONÇANO**
}

\begin{abstract}
MORPHOTECTONIC ANALYSIS OF THE JUQUERIQUERE - PLATEAU, SÃO SEBASTIÂO (SP). Geomorphologic, geologic and tectonic surveys carried out in the Juqueriquerê plateau region, which belongs to the southeastern Brazilian rift system, showed that this landform is made up of a discontinuous erosion surface, still recognizable on hilltops at altitudes varying from 700 to $750 \mathrm{~m}$. This plateau stands some $500 \mathrm{~m}$ below the Moraes plateau and about $200 \mathrm{~m}$ below the Lourenço Velho plateau. The boundary between the Juqueriquerê plateau and the more elevated ones roughly follows the Camburu fault, thus suggesting a tectonic origin for the lowering of the Juqueriquerê plateau. The highest plateau (Moraes plateau) owe its origin to a Paleogene erosion surface, the remains of which can be found on the higher watersheds of the Tietê river, as well as in the highest peaks of the São Sebastião island. Erosional processes increased in the Neogene with the development of the Lourenço Velho plateau at a lower position. The faulting of this latter surface generated the Juqueriquerê plateau. The main regional structural trends originated in the Precambrian and were reactivated in the early Cretaceous, Eocene and early Miocene times. Some of the low intensity earthquakes which have been observed in the area may be related to the latest of these recurrent tectonic movements. The tectonic movements which gave rise to the Juqueriquerê plateau, although most concentrated along the Camburu fault, did not result in a single block, but rather in a series of smaller blocks of varied widths, separated by many smaller faults, which altogether lowered this surface by 200 to 300 meters.
\end{abstract}

Keywords: Morphotectonics, neotectonics, São Sebastião, Juqueriquerê.

\begin{abstract}
RESUMO Investigações geomorfológicas, geológicas e tectônicas, realizadas na região do Planalto do Juqueriquerê, São Sebastião, SP, pertencente ao sistema de rifts da costa sudeste do Brasil, mostraram que esta feição morfológica é constituída por uma superfície erosiva descontínua, ainda reconhecível em topos de morros nivelados entre 700 e $750 \mathrm{~m}$ de altitude, cerca de $500 \mathrm{~m}$ abaixo do Planalto do Moraes e $200 \mathrm{~m}$ abaixo do Planalto do Lourenço Velho. A presença da importante Falha do Camburu, limitando o Planalto do Juqueriquerê daqueles mais elevados ao norte, é sugestiva de origem tectônica para esse desnivelamento. Conclui-se por um modelo de evolução morfotectônica que leva a interpretar, no modelado do relevo atual, restos da superfície paleogênica na região das cabeceiras do Rio Tietê e nas maiores elevações da Ilha de São Sebastião. No Neogeno, desenvolve-se a superficie erosiva do Lourenço Velho, parte da qual é abatida no Mioceno Superior, originando o Planalto do Juqueriquerê. As direcões estruturais, que remontam ao Pré-Cambriano, foram reativadas no Cretáceo Inferior, no Eoceno e no Mioceno Inferior. Sismos de baixa intensidade, ainda hoje observados na região, em parte podem representar as manifestações mais recentes de tal tectonismo recorrente. $\mathrm{O}$ abatimento tectônico do planalto do Juqueriquerê, embora concentrado ao longo da Falha do Camburu, não se deu na forma de um bloco único, mas sim na forma de blocos menores e com larguras variadas, delimitados por diversas falhas de pequeno rejeito, que, no conjunto, propiciaram desnivelamento de 200 a $300 \mathrm{~m}$.
\end{abstract}

Palavras-chave: Morfotectônica, neotectônica, São Sebastião, Juqueriquerê.

INTRODUÇÃO Este trabalho apresenta os resultados de investigações geológicas, geomorfológicas e tectônicas realizadas na região da Serra do Juqueriquerê, onde se desenvolve o planalto homônimo (Cruz 1974, Ponçano et al. 1981, Campanha \& Ens 1992). Esta região situa-se no promontório que se destaca no litoral norte do Estado de- São Paulo, defronte à Ilha de São Sebastião (Fig. 1). Está inclusa no Sistema de Rifts da Serra do Mar (Almeida 1976), renomeado como Rift da Região Sudeste do Brasil, por Riccomini (1989).

O Planalto do Juqueriquerê é formado por morros subnivelados às altitudes de $700-750 \mathrm{~m}$, colocado cerca de $200 \mathrm{~m}$ abaixo do Planalto do Paraitinga e $500 \mathrm{~m}$ abaixo do Planalto Paulistano, conforme representados no Mapa Geomorfológico do Estado de São Paulo (Ponçano et al. 1981). A esse desnivelamento tem sido atribuída origem tectônica, não havendo, porém, estudos anteriores conclusivos a respeito.

A importância da saliência costeira do Juqueriquerê foi destacada já por Almeida (1964); Fúlfaro et al. (1974) reconheceram a existência da importante Falha Camburu, limi- tando o Planalto do Juqueriquerê e sugeriram ter-se originado o planalto por abatimento de bloco. Cruz (1974) reconheceu o Planalto do Juqueriquerê como uma superfície rebaixada, denominando-a Planalto de São Sebastião, enquanto Ponçano et al. (1981) consideraram mais adequada a denominação Planalto do Juqueriquerê e descrevem suas feições geomorfológicas.

A presença da importante Falha do Camburu, limitando o Planalto do Juqueriquerê daqueles mais elevados ao norte, é o primeiro elemento sugestivo de uma origem tectônica para esse desnivelamento. Por outro lado, os planaltos mais elevados são sustentados por rochas granitóides, enquanto o do Juqueriquerê é mantido por gnaisses e migmatitos. Assim, seria possível também considerar que tal desnivelamento topográfico fosse devido aos efeitos da erosão diferencial. A obtenção de dados que balizassem melhor uma dessas hipóteses constituiu o objetivo principal deste trabalho.

GEOMORFOLOGIA Na região em foco, foram reconhecidos três setores de planalto individualizados, apresentando diversos graus de entalhamento pelos sistemas de

\footnotetext{
* Estudo patrocinado pela Financiadora de Estudos e Projetos - Finep

** Divisão de Geologia, Instituto de Pesquisas Tecnológicas do Estado de São Paulo, Cidade Universitária, São Paulo, SP, CEP 05508-901, Fax (011) 869 6383, Fone (011)2682211
} 


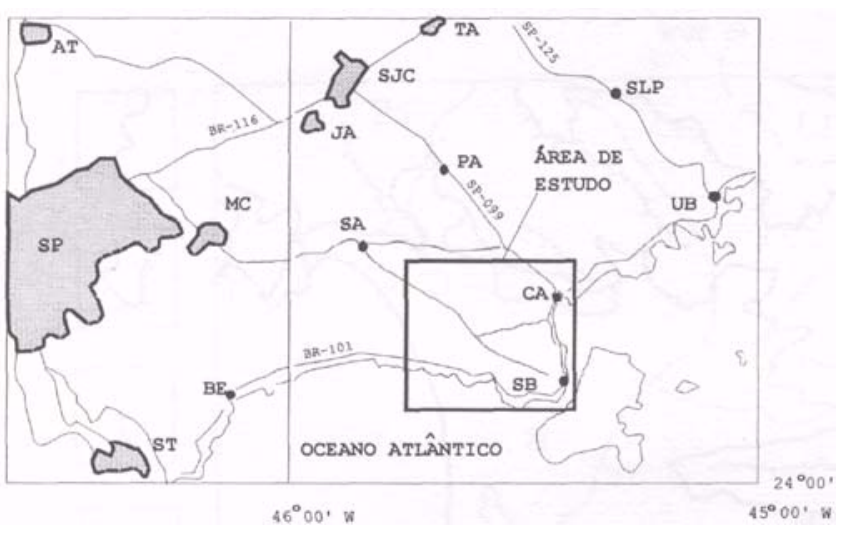

Figura 1 - Localização e acessos das área estudada. (AT) Atibaia; (TA) Taubaté; (SJC) São José dos Campos; (SLP) São Luís do Paraitinga; (JA) Jacareí; (PA) Paraibuna; (SA) Salesópolis; (UB) Ubatuba; (CA) Caraguatatuba; (SB) São Sebastião; (BE) Bertioga; (ST) Santos; (SP) São Paulo; (MC) Moji das Cruzes

Figure 1 - Locality map of the studied area. (AT) Atibaia; (TA) Taubaté; (SJC) São José dos Campos; (SLP) São Luís do Paraitinga; (JÁ) Jacareí; (PA) Paraibuna; (SÁ) Salesópolis; (UB) Ubatuba; (CA) Caraguatatuba; (SB) São Sebastião; (BE) Bertioga; (ST) Santos; (SP) São Paulo; (MC) Moji das Cruzes

drenagem atuais. Separadas desses planaltos por escarpas acentuadas encontram-se as planícies costeiras (Fig. 2).

Tais setores de planalto são caracterizados por relevos de topos subnivelados em diferentes cotas altimétricas, sendo os dois mais elevados aqui denominados Planalto do Moraes e Planalto do Lourenço Velho; o terceiro corresponde ao Planalto do Juqueriquerê (Fig. 3).

O Planalto do Moraes, bem preservado na serra homônima, é o mais elevado de todos, atingindo altitudes em torno de $1.300 \mathrm{~m}$, e abrange essencialmente a região drenada pelas cabeceiras do Rio Tietê e seus tributários, enquanto o Planalto do Lourenço Velho, cujos topos estão em torno de $900 \mathrm{~m}$ de altitude, compreende as bacias do Rio Lourenço Velho e do Ribeirão dos Prazeres.

O Planalto do Moraes parece integrar o Planalto Paulistano, como definido por Almeida (1964) e representado no Mapa Geomorfológico do Estado de São Paulo (Ponçano et al. 1981). Entretanto, tendo em vista que a área em análise é restrita e associada ao importante divisor de águas Tietê Paraibuna, não se pode descartar a hipótese de tratar-se de remanescente de uma fase erosiva anterior à instalação do Planalto Paulistano, ou seja, de um relevo cujos cimos atingem altitudes condizentes com a posição da Superfície Japi (Almeida 1964).

Em sua porção sudoeste, na área estudada, o Planalto do Moraes apresenta limite abrupto com a província costeira, através de escarpas festonadas de grande amplitude da Serra do Mar. Para nordeste, seu limite com o Planalto do Lourenço Velho, drenado pelos tributários do Rio Paraibuna, dá-se por meio de escarpa erosiva de cerca de $300 \mathrm{~m}$. Para sul e sudeste, o profundo entalhamento produzido pelo Rio Pardo (Camburu) originou relevo de montanhas com vales profundos, em que os topos mais elevados preservam ainda altitudes localmente superiores a $1.200 \mathrm{~m}$.

Um último resto do Planalto do Moraes avança ainda mais para leste, onde é drenado e entalhado pelos tributários do Rio Paraibuna (Ribeirão dos Prazeres e Rio Lourenço Velho); aqui as cotas mais elevadas ainda ultrapassam os $1.100 \mathrm{~m}$.

Os limites entre as três unidades associadas ao Planalto do Moraes são configurados basicamente pelos divisores d'águas Tietê-Camburu e Camburu-Parafbuna, indicando que o grau de entalhamento e degradação do planalto original possa ser decorrente da altitude e distância do nível de base da rede de drenagem.

$\mathrm{Na}$ porção centro-norte da área estudada, e em estreita faixa contornando os remanescentes do Planalto do Moraes ao longo de sua borda sul, situa-se o Planalto do Lourenço Velho, que pode ser correlacionado ao Planalto de Paraitinga (Almeida 1964), conforme representado no Mapa Geomorfológico do Estado de São Paulo (Ponçano et al. 1981).

A porção menos entalhada desse planalto, cujas maiores altitudes estão em torno dos $900 \mathrm{~m}$, ocorre em estreita faixa adjacente à escarpa que despenca para a Planície de Caraguatatuba e contém o divisor d'águas entre a bacia hidrográfica do Paraibuna e as águas que são drenadas para o litoral.

Outra feição marcante do Planalto do Lourenço Velho relaciona-se à porção da bacia do rio homônimo, que se constitui em escarpa ravinada de até $200 \mathrm{~m}$, separando-o do Planalto do Moraes. Esta escarpa indica maior juventude do Lourenço Velho relativamente ao Planalto do Moraes.

Contornando o Planalto do Moraes pelo sul, em continuidade com a porção melhor preservada do Planalto do Lourenço Velho, estende-se uma faixa de morros cujas cotas mais elevadas atingem $900 \mathrm{~m}$, verificando-se gradual decréscimo para sul, onde as maiores elevações situam-se ao redor dos $750 \mathrm{~m}$, devido à ação erosiva dos tributários dos Rios Camburu e Cubatão. O Rio Pardo (Camburu), que adentra esta unidade proveniente do Planalto do Moraes fortemente entalhado, muda abruptamente de gradiente, passando a correr em vale mais amplo. O limite sul, com o Planalto do Juqueriquerê, é notavelmente retilíneo, sendo demarcado pela drenagem fortemente encaixada na Falha do Camburu.

O Planalto do Juqueriquerê, inicialmente reconhecido por Cruz (1974), que o denominou Planalto de São Sebastião, é uma notável saliência costeira, que ocupa a porção central da área enfocada neste estudo.

Com exceção do limite retilíneo demarcado pela Falha do Camburu, separando-o do Planalto do Lourenço Velho, o Planalto do Juqueriquerê é limitado pelas escarpas da Serra do Mar (da qual se destaca como um promontório), que aqui contornam a saliência costeira.

O Planalto do Juqueriquerê apresenta altitudes entre 600 e $750 \mathrm{~m}$, com topos de morros entre 700 e $750 \mathrm{~m}$, destacando-se nele a Serra do Dom, onde as maiores elevações atingem valores superiores a $800 \mathrm{~m}$. Os relevos que o constituem dispõem-se em patamares, configuração que se torna mais evidente na região localizada entre Boiçucanga e a Serra do Dom, onde o forte entalhamento da drenagem chega a isolar pequenos restos de planalto. Estes apresentam distintos nivelamentos, que podem ser interpretados como resultado de movimentação tectônica de blocos num padrão de horst e graben.

$\mathrm{O}$ divisor d'águas que separa as bacias hidrográficas drenadas para a planície de Caraguatatuba, daquelas que deságuam para sul, corre ao longo de toda a borda sul e oeste do Planalto do Juqueriquerê, o que, aliado à drenagem, que sobre o planalto tende a correr para NE, e à distribuição das maiores elevações, delineia uma superfície de topo de planalto mergulhando suavemente para NE. Note-se que o Planalto do Lourenço Velho tem caimento também para NE, enquanto o do Moraes cai para NW.

GEOLOGIA A área estudada é constituída essencialmente por rochas do embasamento cristalino, de idade précambriana, situadas a sul do Lineamento de Cubatão e atribuídas freqüentemente ao Complexo Costeiro. São cortadas por enxames de diques do Jurássico Superior e Cretáceo Inferior, além de expressivas coberturas sedimentares quaternárias associadas às baixadas litorâneas (Fig. 4).

O embasamento cristalino é constituído de rochas para e ortoderivadas, de médio e alto grau metamórfico, e rochas 


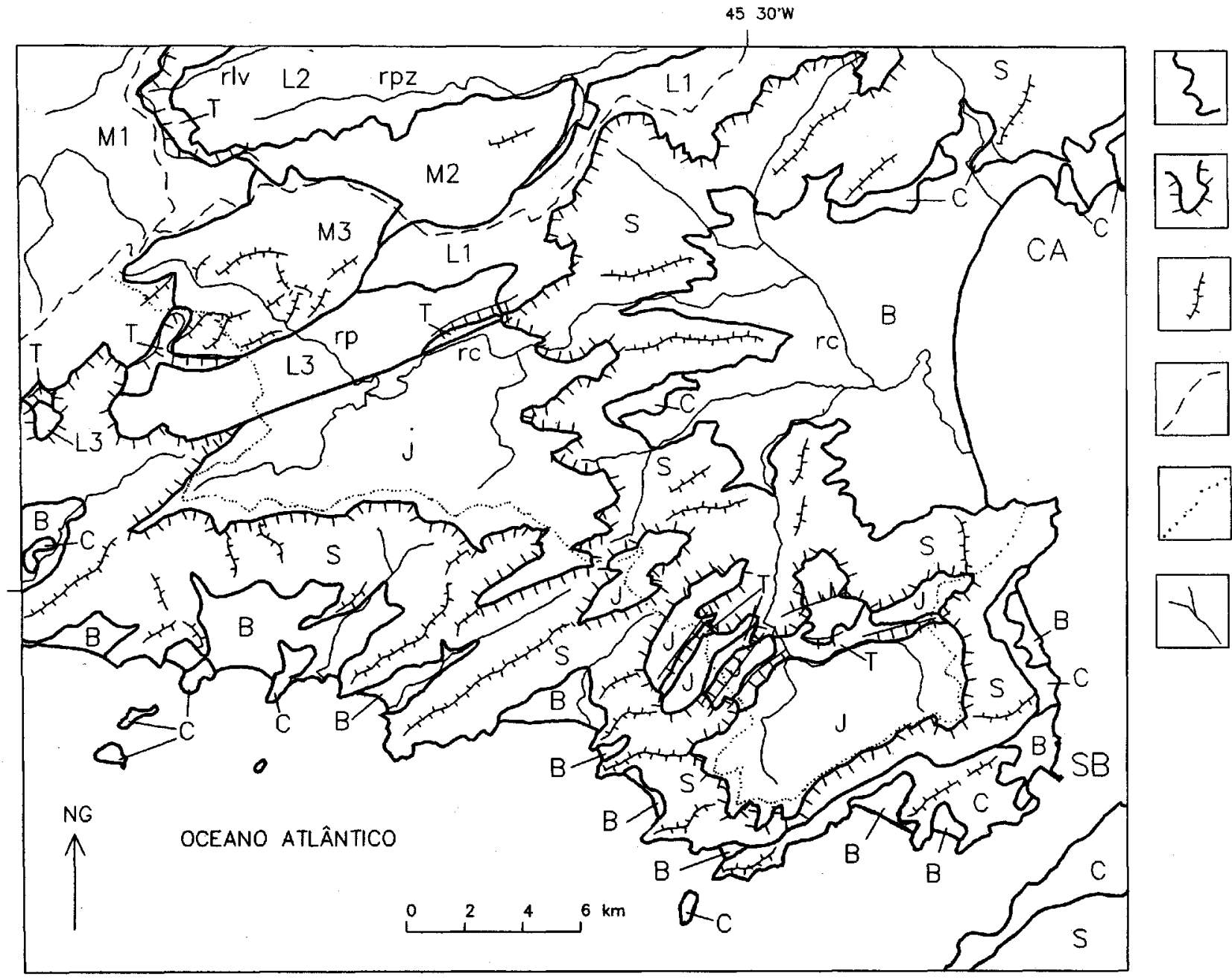

Figura 2-Mapa Geomorfológico do Planalto do Juqueriquerê e áreas adjacentes: (1) limite entre unidades geomorfológicas; (2) limite superior de relevo escarpado; (3) crista; (4) divisores de água principais (Tietê - Paraibuna, Tietê - litoral, Paraibuna -Litoral); (5) divisor de água entre as drenagens para a planície de Caraguatatuba e para o oceano a sul; (6) rede de drenagem principal; (Ml) Planalto do Moraes - morros paralelos; (M2) Planalto do Moraes - serras alongadas; (M3) Planalto do Moraes - montanhas com vales profundos; (LI) Planalto do Lourenço Velho - morrotes alongados e morros paralelos; (L2) Planalto do Lourenço Velho - morros paralelos com vales abertos; (L3) Planalto do Lourenço Velho - morros paralelos com vales fechados; (J) Planalto do Juqueriquerê; (S) escarpas festonadas e digitadas; (T) relevo de transição; (B) baixadas litorâneas; (C) morraria costeira; (CA) - Caraguatatuba; (SB) - São Sebastião; (rpz) Ribeirão dos Prazeres; (rlv) Rio Lourenço Velho; (rp) Rio Pardo; (rc) Rio Camburu

Figure 2 - Geomorphologic map of the Juqueriquerê plateau and adjacent areas: (1) boundary between geomorphologic units; (2) upper boundary of escarpment; (3) crest; (4) main drainage divides (Tietê - Paraibuna, Tietê - coastline, Paraibuna - coastline); (5) drainage divide between waters flowing to the Caraguatatuba plain and to the ocean to the south; (6) main drainage; (Ml) Moraes Plateau - parallel hills; (M2) Moraes Plateau - long hills; (M3) Moraes Plateau - mountains with deep valleys; (LI) Lourenço Velho Plateau - long small hills and parallel hills; (L2) Lourenço Velho Plateau - parallel hills with open valleys; (L3) Lourenço Velho Plateau - parallel hills with narrow valleys; (J) Juqueriquerê Plateau; (S) festooned and digitated escarpments; (T) transitional relief; (B) low coastal plains; (C) low coastal hills; (CA) Caraguatatuba; (SB) São Sebastião; (rpz) Prazeres river; (rlv) Lourenço Velho River; (rp) Pardo River; (rc) Camburu River

granitóides deformadas e gnaissificadas em intensidades variáveis.

A correlação dessas rochas com unidades litoestratigráficas regionais, bem como suas idades, são assuntos controversos, percebendo-se na literatura diversas tendências. Almeida et al (1981) as atribuem ao Complexo Costeiro, de idade arqueana, porém com retrabalhamento e granitogênese policíclicas, o que justificaria as idades brasilianas obtidas na maioria das datações geocronológicas. Já, Campos Neto \& Figueiredo (1992) atribuem as rochas da região a terrenos da Orogênese Rio Doce, de idade neoproterozóica a cambriana.

Ao longo do perfil Bairro de São Lourenço a São Sebastião, levantado em detalhe, foram reconhecidos dois con- juntos de rochas, separados pela Zona de Cisalhamento do Camburu: a NW desta feição encontram-se rochas granitóides gnaissificadas (Granito Pico do Papagaio), enquanto a SE ocorre um conjunto de rochas predominantemente paraderivadas migmatizadas, com importante contribuição de rochas metabasíticas.

A Falha do Camburu constitui uma faixa de dezenas a centenas de metros de espessura de rochas miloníticas, ultramiloníticas, blaslomiloníticas e protomiloníticas, predominantemente quartzo feldspáticas. O ramo que desvia para leste, que é acompanhado pelo curso do Rio Camburu e adentrando a planície costeira de Caraguatatuba, foi interpretado como sendo a falha principal por Melo \& Pires Neto (1977). 


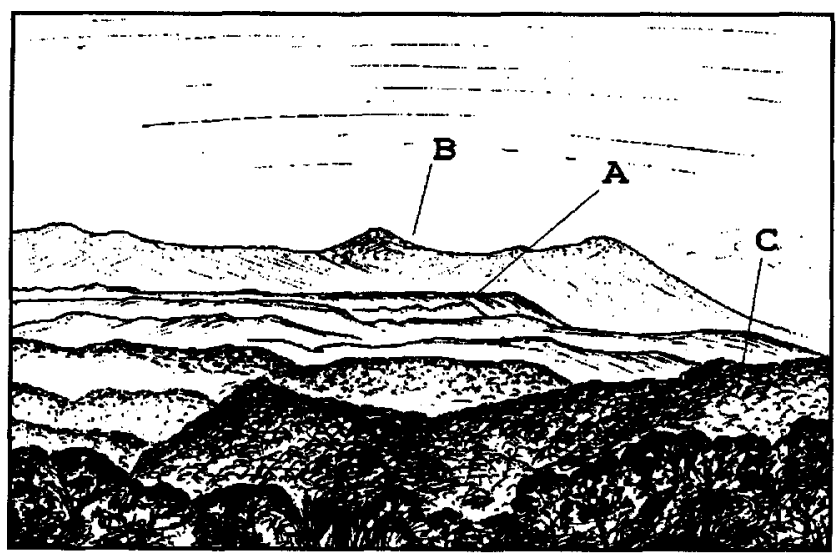

Figura 3 - Vista do Planalto do Juqueriquerê (A), a partir do Planalto do Moraes. Ao fundo (B), observa-se a Ilha de São Sebastião, com cotas que atingem até L $300 \mathrm{~m}$. Em primeiro plano $(\boldsymbol{C})$, observa-se o relevo montanhoso residual do Planalto do Moraes. Desenhado a partir de fotografia Figure 3 - View of the Juqueriquerê plateau (A) from the Moraes Plateau. São Sebastião island in the background (B), which reaches $1,300 \mathrm{~m}$ in altitude. Residual mountainous relief of the Moraes plateau (drawn from a photograph) in the foreground (C)

Rochas anfibolíticas são comuns em toda a região a SE da Falha do Camburu, concentrando-se em duas faixas, entre a Praia do Juqueí e Boiçucanga, e entre Maresias e a Praia da Samiagem. Ocorre uma série de diques anfibolitizados na região do Bairro do Marisco (Silva et al. 1977), na península do Baleeiro (Coutinho et al. 1991), tendo sido também observados cortando o Granito Pico do Papagaio, no Bairro de São Lourenço, e um quartzito nas proximidades da Praia do Guaecá.

Na região de São Sebastião, ocorre ainda pequeno corpo concordante de rochas granitóides leucocráticas foliadas, ricas em granada, cujas melhores exposições encontram-se na Praia do Guaecá, ao redor da gruta denominada Buraco do Bicho, e na Ponta do Guaecá.

Na Ilha de São Sebastião, o embasamento cristalino parece constituir-se, pelo que relata a literatura, essencialmente de granitóides porfiríticos foliados.

No final do Jurássico e início do Cretáceo, a região estudada foi palco de intensa atividade magmática, representada por centenas de diques de rochas básicas, ultrabásicas e intermediárias, de caráter toleítico e alcalino, com idades em torno de $120 \mathrm{Ma}$ (Coutinho et al. 1992). Suas características petrográficas foram descritas por Coutinho et al. (1991).

As rochas toleíticas estão representadas por diques de diabásios e microdioritos pórfiros, com espessuras de até $50 \mathrm{~m}$ e orientação NE, concordante com a direção das estruturas regionais. Estes diques parecem concentrar-se especialmente nas imediações da Falha do Camburu, encaixados na foliação milonítica.

Rochas máficas e ultramáficas de caráter alcalino ocorrem na forma de centenas de diques estreitos, com espessuras médias em torno de $1 \mathrm{~m}$, e direção concordante com as estruturas regionais. Estes diques parecem concentrar-se em determinadas faixas, destacando-se os costões nas imediações de São Sebastião (Ponta do Araçá), onde Coutinho et al. (1991) observaram até 20 diques em perfil de $200 \mathrm{~m}$, indicando distensão crustal mínima da ordem de $5 \%$.

Na Ilha de São Sebastião, ocorrem ainda rochas intrusivas alcalinas eocretáceas (Amaral et al. 1967, Hennies \& Hasui 1968) de caráter essencialmente sienítico, do stock de São Sebastião (Freitas 1947).

Sedimentos inconsolidados de origem continental e marinha, cujas características principais podem ser referidas a
Suguio \& Martin (1978) e Souza (1990), ocupam grandes áreas nas baixadas litorâneas, destacando-se a Planície de Caraguatatuba. A sedimentação atual no Canal de São Sebastião foi estudada por Furtado (1978).

TECTÔNICA Estruturas dúcteis As rochas pré-cambrianas aflorantes na área caracterizam-se pela presença quase constante de foliação metamórfica penetrativa em todas as escalas. Varia na intensidade de sua trama, podendo normalmente ser caracterizada como xistosidade e/ou foliação gnáissica e, nas faixas mais deformadas, como foliação milonítica.

Dobras intrafoliais de porte decimétrico, associadas à essa foliação/bandamento gnáissico, são observadas raramente nas rochas gnáissico-migmatíticas bandadas. Feições de boudinage de corpos mais competentes, como anfíbolitos, são mais comuns.

Essa foliação assume, na área, disposição tipicamente em leque. Na porção central da área, em torno da Falha do Camburu, mostra posições empinadas, quase que verticalizadas; conforme caminha-se para sudeste, essa foliação vai mostrando mergulhos progressivamente menores, em geral para norte, até atingir uma zona de cisalhamento de baixo ângulo, junto à costa. Para noroeste, inversamente, a foliação mostra mergulhos progressivamente mais suaves para sul, achando-se afetada localmente por uma série de zonas de cisalhamento verticais de menor porte, com larguras da ordem de metros a dezenas de metros.

A Falha do Camburu caracteriza-se, no tocante às suas deformações mais antigas, provavelmente pré-cambrianas a eo-paleozóicas, como uma zona de cisalhamento dúctil, balizada por milonitos, protomilonitos e ultramilonitos. As lineações de estiramento observadas são suborizontais. A assimetria de porfiroclastos sugere movimentação de caráter transcorrente dextral.

Outra zona de cisalhamento importante ocorre na região litorânea, com boas exposições nas pontas do Baleeiro e do Guaecá. Caracteriza-se como um empurrão de baixo ângulo, colocando rochas granitóides sobre migmatitos bandados. O sentido da vergência é para sul, conforme indicado pelas lineações de estiramento, assimetrias de porfiroclastos e de dobras de fluxos. Feições espetaculares de dobramento, boudinage e deformação de diques básicos pré-cambrianos são observadas na porção central da zona de cisalhamento. Numa faixa central ainda mais estreita, com espessura da ordem de metros, desenvolvem-se milonitos, ultramilonitos e protomilonitos.

Outras zonas de cisalhamento menores observadas mostram, em geral, caráter oblíquo ou direcional de movimentação.

A disposição em leque das estruturas em torno da Falha do Camburu, com a ocorrência de empurrões divergentes nos blocos norte e sul, caracteriza estrutura em flor positiva e sugere caráter transpressivo para a deformação dúctil que ocorreu na área (Campanha \& Ens 1993).

Estruturas rúpteis As estruturas associadas à deformação rúptil que ocorrem na área compreendem sistemas de juntas, planos estriados (slickensides), diques de rochas básicas e alcalinas, e zonas de brechação cataclástica.

A reativação de estruturas antigas é muito nítida. $\mathrm{Na}$ Falha do Camburu, ocorrem diques de rochas básicas com até $50 \mathrm{~m}$ de espessura, encaixados na foliação milonítica das rochas. Nessa mesma zona de falha, ocorrem planos estriados, paralelos à foliação milonítica, com estrias de atrito denotando movimentação normal, por vezes associadas a faixas brechadas cataclasticamente, com até $3 \mathrm{~m}$ de espessura, afetando inclusive os diques. Estas feições cataclásticas mais expressivas foram observadas ao longo do leito do Rio Camburu, a jusante da estrada de Salesópolis a São Sebastião. 


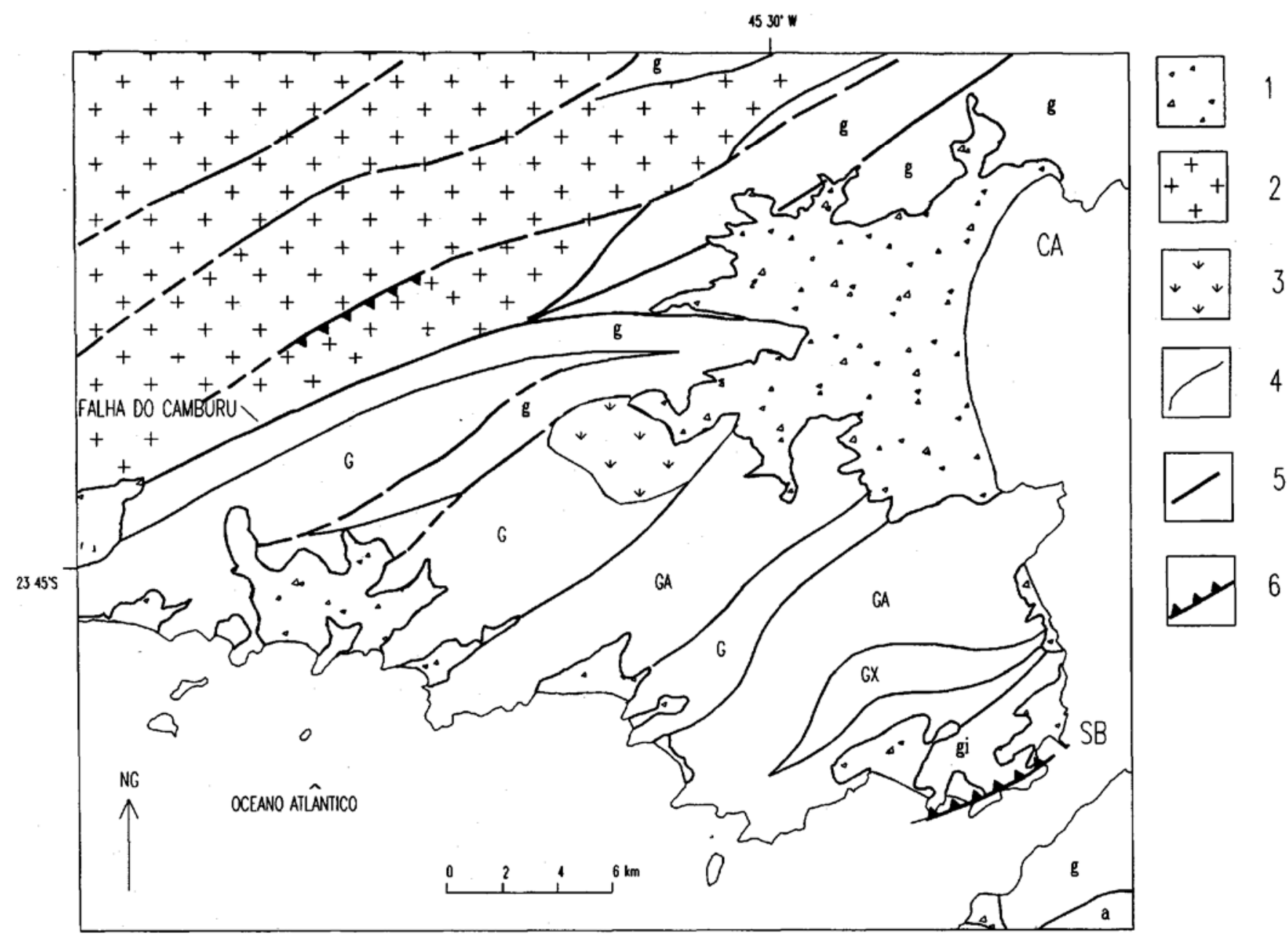

Figura 4 - Mapa Geológico do Planalto do Juqueriquerê e áreas adjacentes: (1) sedimentos quaternários; (2) granitóides gnáissicos (Granito Pico do Papagaio); (3) metagabros, metadioritos e enderbitos parcialmente migmatizados (Complexo Bairro do Marisco); (4) contatos; (5) zonas de cisalhamento transcorrentes; (6) zonas de cisalhamento de cavalgamento; (a) rochas sieníticas alcalinas da Ilha de São Sebastião; (g) granitóides gnáissicos eqüigranulares, oftálmicos e nebulíticos; subordinadamente gnaisses, xistos e anfibolitos; (gi) leucogranito gnáissico com granada; (G) biotita gnaisses e migmatitps freqüentemente com granada e sillimanita; subordinadamente anfibolitos, kinzigitos, corpos nebulíticos e rochas cálciosilicáticas; (GA) biotita gnaisses e migmatitos com freqüentes intercalates de anfibolitos; (GX) biotita gnaisses existos com intercalates de quartzitos; (CA) Caraguatatuba; (SB) São Sebastião

Figure 4 - Geologic map of the Juqueriquerê Plateau and adjacent areas: (1) quaternary sediments; (2) Pico do Papagaio Gneissic Granite; (3) metagabbros, metadiorites and enderbites partially migmatized (Bairro do Marisco Complex); (4) contacts; (5) transcurrent shear zones; (6) thrust shear zones; (a) alkaline syenitic rocks of São Sebastião Island; (g) equigranular, ophthalmic and nebulitic gneissic granitoids; (gi) garnet bearing gneissic leucogranite; (G) biotite gneiss and migmatites often with garnet and sillimanite; subordinate amphibolites, kinzigites, nebulitic bodies and calcsilicate rocks; (GA) biotite gneiss and migmatites with amphibolite; $(\boldsymbol{G X})$ biotite gneisses and schists with quartzite intercalations; (C A) Caraguatatuba; (SB) São Sebastião

Na região litorânea, esse condicionamento das estruturas de reativação pelas estruturas antigas do embasamento não é aparente. Nesse local, as estruturas antigas dúcteis (foliação, bandamento gnáissico) mostram atitude de baixo ângulo, enquanto as estruturas de reativação (diques, juntas, pequenas falhas) assumem posição empinada, praticamente perpendicular às estruturas antigas. Ressalte-se, no entanto, que as estruturas de reativação nessa região, embora localmente discordantes de estruturas antigas, são a elas paralelas em termos regionais.

Planos esfriados No campo, procurou-se analisar e medir sistematicamente todos os planos estriados (slickensides) observados. Estruturas de falha de grande porte em geral não foram observadas, mas sim um conjunto muito grande de pequenas falhas, dispostas em atitudes muito variadas, por vezes associadas com brechas e material pulverizado de espessura submilimétrica até centimétrica, por vezes asso- ciadas simplesmente com uma superfície argilosa, extremamente polida pelo atrito. Exceção são as faixas de até $3 \mathrm{~m}$ de espessura de brechas cataclásticas observadas ao longo da Falha do Camburu.

Os dados referentes às pequenas falhas foram tratados estatisticamente, em termos de orientação do plano de falha e das estrias e em termos da determinação de direções de esforços médios, pelo método de Arthaud (1969), revisado por Aleksandrowski (1985).

Os dados de orientação de planos estriados, estrias e "planos de movimento" (Arthaud 1969) foram plotados em diagramas Schmidt-Lambert, separadamente para os domínios a norte da Falha do Camburu, a sul da Falha do Camburu, e para a área total (Fig. 5); para esses mesmos domínios, foram plotadas as atitudes de foliação metamórfica.

Numa avaliação preliminar desses dados, pode-se inferir que o conjunto de pequenas falhas foi gerado por um sistema de esforços médio, de natureza triaxial, com direção princi- 

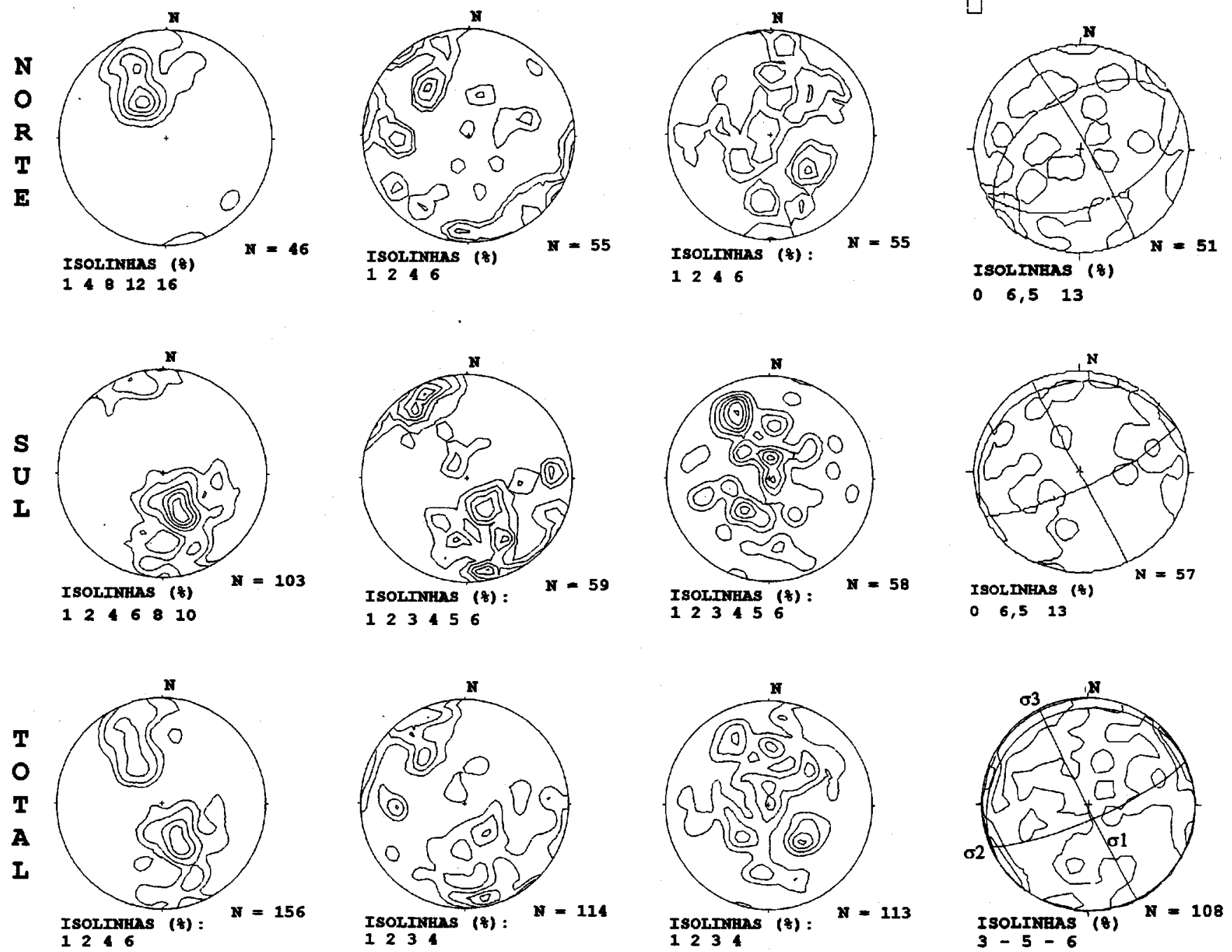

Figura 5 - Estereogramas de dados estruturais - redes de Schmidt-Lambert, semi-esfera inferior, isolinhas de freqüência por $1 \%$ de área do diagrama, discriminados para o domínio ao norte da Falha do Camburu, ao Sul da Falha do Camburu, e para a área total

Figure 5 - Structural data stereograms for the domains north and south of the Camburu fault, and for the total area (Schmidt-Lambert net, lower hemisphere, frequency isolines per $1 \%$ of net area)

pal de compressão sub vertical (sigma $1=154 / 76)$, direção principal de extensão NNW horizontal (sigmaS = 335/14), e direção principal intermediária ENE ( $\operatorname{sigma2}=65 / 0)$.

Uma inferência pode ser feita com relação à espessura das faixas cataclásticas associadas às falhas. Marrett \& Allmendinger (1990) apresentam gráfico de correlação entre a espessura do material moído e o deslocamento ao longo de falhas rúpteis. Para uma zona brechada de $3 \mathrm{~m}$ de largura, como a observada ao longo do Rio Camburu, o deslocamento previsto é da ordem de 200 a $300 \mathrm{~m}$, o que é suficiente para explicar o desnivelamento existente entre o Planalto do Juqueriquerê e a Superfície do Lourenço Velho. Considerando-se que ocorrem vários níveis menores de brechas (da ordem de centímetros de espessura), a somatória de todos os pequenos deslocamentos forneceria um valor ainda maior. Ressalte-se que esses diagramas de correlação são precários, baseados em dados empíricos e em modelagens do processo cataclástico baseadas na geometria fractal.

Diques e estruturas associadas Os diques de rochas básicas concentram-se em algumas faixas, como por exem- plo na península costeira de São Sebastião e na Falha do Camburu. $\mathrm{Na}$ península costeira, ocorrem com densidade particularmente grande, embora em geral sejam pouco espessos, mostrando, graças a boas exposições, padrões ramificados e entrelaçados. Na região da Falha do Camburu, ocorrem diques mais espessos (até $50 \mathrm{~m}$ ), encaixados na foliação milonítica. Porém, devido a cobertura vegetal e de solos, não foi possível observar de modo mais completo seu padrão de distribuição. Diques menores distribuem-se amiúde por todo o restante da área.

Muitos diques mostram planos estriados nos seus contatos com a encaixante, ou mesmo no seu interior. Em geral, são superfícies simples, com rejeito muito pequeno (centimétrico, raramente decimétrico). Na Falha do Camburu, foram observados diques cortados por zonas brechadas mais espessas. Demonstram deformação do dique já em estado rígido. Por outro lado, em um dique na região costeira foram observadas fraturas de extensão com cristais fibrosos de calcita denotando extensão aproximadamente perpendicular às paredes do dique. Como a rocha está alterada hidrotermalmente, provavelmente por fluidos finais associados ao 
magmatismo, o movimento associado à intrusão do dique deve ter sido de extensão perpendicular às paredes.

$\mathrm{O}$ diagrama de Schmidt-Lambert, das atitudes medidas dos diques mostra direção predominante NE, com mergulhos variáveis (Fig. 6).
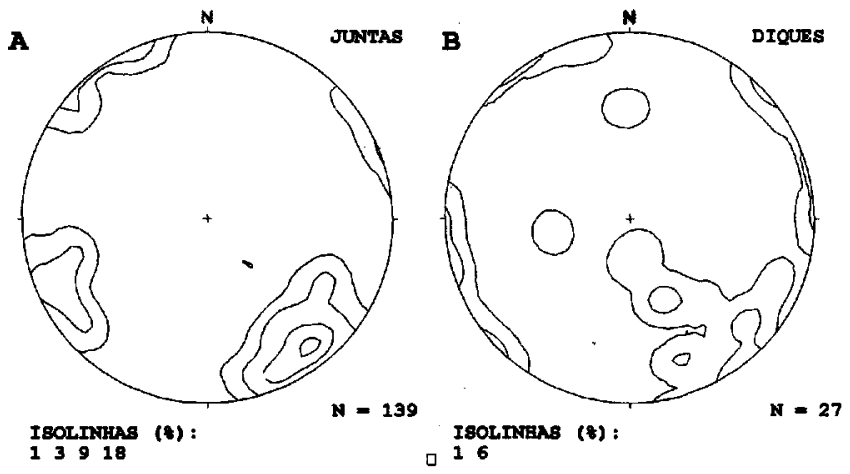

Figura 6-Estereogramas de atitudes de diques e juntas Figure 6 - Stereograms of attitudes of dikes and joints

Na península costeira de São Sebastião, os diques mostram atitude ENE subvertical, discordante das estruturas do embasamento, suborizontais. Aí, os diques associam-se a um conjunto de fraturas a eles paralelos, bastante longas e persistentes, com extensões mínimas de até dezenas de metros (no limite das extensões rochosas aflorantes).

A maior parte dos conjuntos de fraturas não mostra relações temporais claras com relação aos diques. Algumas fraturas, no entanto, cortam indiscriminadamente o embasamento e os diques, demonstrando a ocorrência de fraturamento posterior à intrusão e solidificação dos diques.

$\mathrm{Na}$ região costeira, foram por vezes observadas faixas de brechas cataclásticas com espessura até métrica (e.g., Buraco do Bicho). Em alguns locais, observou-se que brechas desse tipo estavam associadas espacialmente com os diques, dispostas lateralmente, no centro dos diques ou em suas terminações. Não se logrou observar feições indicativas de movimento cisalhante (i.e., pequenas falhas) na encaixante, brechas ou diques, o que leva a supor que essas brechas cataclásticas tenham sido geradas na intrusão dos diques pelo mecanismo de fraturamento hidráulico, segundo o qual, quanto maior a pressão de fluidos, menor é a resistência à ruptura de rocha. Particularmente, quando submetidas a um esforço hidrostático de tração, e este iguala o valor das forças coesivas que mantêm juntas as partículas, as rochas rompem-se com violência explosiva (Ramsay 1967).

Fotolineamentos e fraturas Para análise do padrão de fraturamento da área, foram coletadas atitudes de juntas em dois afloramentos; foram também traçados fotolineamentos a partir de fotos aéreas de escala 1:60 000 .

Nas fotos aéreas, foram traçados principalmente os fotolineamentos negativos (depressões lineares do relevo), relativamente longos, supostamente correspondentes a fraturas maiores e, talvez, diques e zonas brechadas. Evitou-se traçar os fotolineamentos de padrão mais denso e comprimento menor, provavelmente correspondentes à foliação metamórfica. Foram traçadas, também, com outra simbologia, as cristas morfológicas (fotolineamentos positivos), que foram lançadas no mapa geomorfológico.

Foram construídas rosáceas de direções para os fotolineamentos interpretados, uma para o domínio a norte da Falha do Camburu, e outra para o domínio a sul desta (Fig. 7).

O domínio a sul da Falha do Camburu mostra sistema relativamente simples de lineamentos (Fig. 7), com direção preferencial de N65E, e uma segunda direção preferencial aproximadamente perpendicular a esta, a N30W. Essas direções coincidem, respectivamente, com a direção da foliação metamórfica e com a direção a ela ortogonal. A primeira direção coincide, também, com a direção preferencial dos diques básicos. Ocorre, ainda, pelo menos um outro conjunto importante de fotolineamentos neste domínio, a N85W.

O domínio a norte da Falha do Camburu mostra padrão semelhante de fotolineamentos, porém com maior participação da direção N30W, perpendicular à foliação metamórfica. Tal fato provavelmente se deve à menor anisotropia das rochas a noroeste da Falha do Camburu, constituídas por granitóides mais ou menos foliados, enquanto as rochas a sudeste dessa falha são constituídas por migmatitos e gnaisses bandados, com bandamento composicional, em geral intenso paralelo à xistosidade e gnaissificação.

$\mathrm{O}$ padrão obtido nas atitudes de juntas na península do Baleeiro (Fig. 6) é essencialmente coerente com o de fotolineamentos. Observa-se dois conjuntos predominantes de juntas, com mergulhos subverticais, um paralelo e outro aproximadamente perpendicular à foliação metamórfica regional.

DISCUSSÃO A configuração do relevo dos planaltos cristalinos do sudeste brasileiro foi objeto de trabalhos clássicos ( $c f$. Ponçano \& Almeida 1993), como os de Ruellan (1944), Freitas (1951) e Almeida (1964), que enfatizam o controle estrutural e a origem tectônica do relevo escalonado dos planaltos cristalinos da Região Sudeste do Brasil. King (1956), por sua vez, atribui os diversos níveis planálticos a sucessivos ciclos erosivos e de soerguimento epirogênico.

Outra linha explicativa para a origem desses planaltos foi elaborada por meio de conceitos de geomorfologia climática, que atribuem a formação de superfícies aplainadas a processos de pedimentação e pediplanação durante fases áridas (e.g. Bigarella \& Ab'Saber 1964, Bigarella \& Andrade 1965). Nessa concepção, um pediplano formado durante um ciclo árido passa a ser dissecado e entalhado pela drenagem numa fase climática úmida subseqüente, e uma nova fase árida propiciaria a instalação de nova superfície pedimentar rebaixada em relação à primeira, resultando ao final de diversos ciclos na formação de planaltos situados a altitudes distintas. A influência de movimentos tectônicos no modelado do relevo não é excluída, passando, porém, a ter importância secundária, nessa concepção.

Mais recentemente, o fator tectônico vem sendo enfatizado na evolução geológica cenozóica do sudeste brasileiro, por autores tais como Almeida (1976), Asmus \& Ferrari (1978), Melo et al. (1985), Riccomini (1989), Melo (1990) e Salvador (1994). Modelos para as deformações tectônicas cenozóicas foram também propostos (Campanha et al. 1985, Riccomini 1989, Melo et al 1985, Zalan 1986, Macedo et al 1991). Esses trabalhos enfocam principalmente os aspectos da evolução sedimentar, tectônica e vulcânica das bacias sedimentares associadas aos rifts; os de Almeida (1976) e Salvador (1994) integram aspectos geomorfológicos em suas análises, enquanto os demais não abordam extensivamente a tectônica como fator morfogenético regional.

Este trabalho pretende contribuir para a compreensão das relações entre tectônica e morfogênese das regiões cristalinas do sudeste por intermédio dos elementos fornecidos pela região do Planalto do Juqueriquerê, onde foram encontradas evidências de participação de eventos tectônicos na configuração atual do relevo.

Três planaltos foram aí identificados, cujos topos correspondem a morros subnivelados a $1.150-1.300,900-950 \mathrm{e}$ 700 - $750 \mathrm{~m}$ de altitude, aqui atribuídos aos Planaltos do Moraes, do Lourenço Velho e do Juqueriquerê (Fig. 2 e 8). A discussão que segue admite que os topos dos planaltos correspondem a superfícies erosivas desenvolvidas em lapsos de tempo relativamente bem definidos. 
NORTE

A

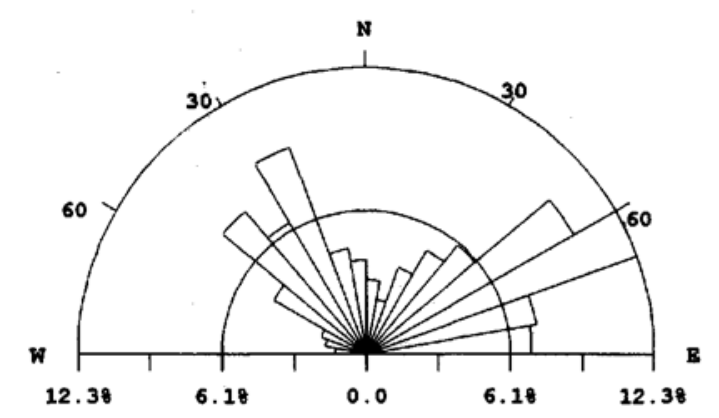

B

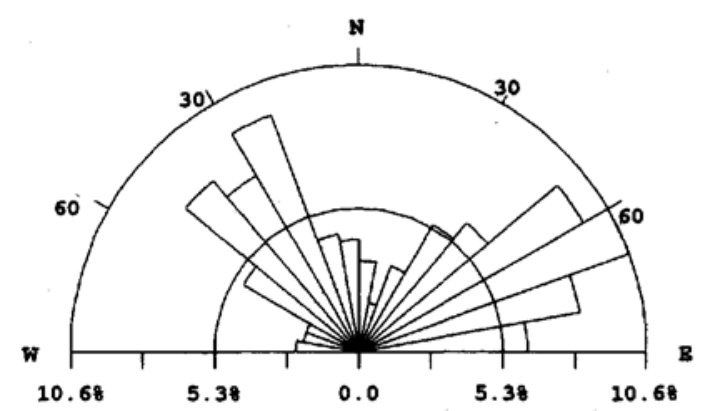

SUL
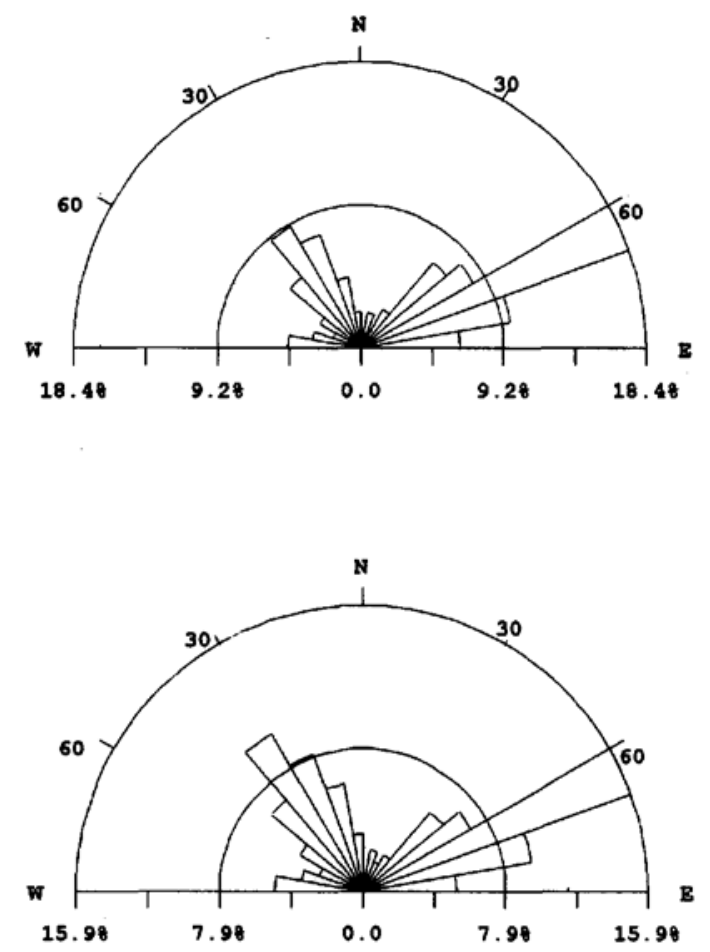

Figura 7 - Rosáceas de somatória de comprimento de fotolineamentos versus orientação (A) e de freqüência defotolineamentos versus orientação (B), para os domínios a norte e a sul da Falha do Camburu

Figure 7 - Rose diagrams for total photolineament length versus orientation (A) and for frequency of photolineaments versus orientation (B) for the northern and southern domains of the Camburu fault

O Planalto do Moraes, balizado pela superfície erosiva mais elevada, apresenta-se melhor preservado nas cabeceiras do Rio Tietê. A superfície correspondente ao Planalto do Lourenço Velho, apresenta avanço erosivo ao longo do rio homônimo, às custas dos relevos que correspondem ao Planalto do Moraes, sendo o limite entre os dois marcado por escarpa de até $300 \mathrm{~m}$. Outro remanescente do Planalto do Lourenço Velho foi identificado contornando pelo sul o Planalto do Moraes, aqui fortemente degradado pela drenagem que corre para o mar. No extremo oeste da área estudada, um pequeno resto correlacionável ao Planalto do Lourenço Velho forma um patamar inserido na escarpa da Serra do Mar. Estas feições sugerem ser o Planalto do Moraes mais antigo que o do Lourenço Velho.

Outra possibilidade é esses planaltos terem sido desnivelados por falhamentos normais. Não foi observada falha que justificasse essa hipótese, embora as direções N-S e NW-SE correspondam às direções subordinadas dos sistemas de juntas, espelhos de falha e da orientação de diques observados na área.

A porção central da área enfocada é dominada pelo Planalto do Juqueriquerê, que apresenta os topos dos morros nivelados a altitudes entre 700 e $750 \mathrm{~m}$.

Para sudeste, fora da área estudada, ocorrem novamente elevações maiores na Ilha de São Sebastião. Não há ali restos preservados de superfícies aplainadas; ainda assim os anéis externos dos stocks da Ilha de São Sebastião apresentam-se a altitudes semelhantes àquelas observadas no Planalto do Moraes.

A configuração morfológica que surge assim é a de uma superfície erosiva mais antiga, preservada na Serra do Moraes e cabeceiras do Rio Tietê e ainda nivelando as cotas mais elevadas da Ilha de São Sebastião, e uma superfície mais recente originada pela atuação de processos erosivos sobre a mais antiga, representada hoje pelo Planalto do Lourenço Velho. O Planalto do Juqueriquerê poderia corresponder a uma dessas superfícies, tectonicamente abatida. Poderia ainda ser relacionado a uma outra superfície erosiva, instalada mais recentemente, ou concomitantemente com uma das anteriores, sendo mais baixa devido aos efeitos da erosão diferencial ou de nível de base diferente.

Entretanto, o Planalto do Juqueriquerê apresenta limite marcadamente retilíneo com relação ao Planalto do Lourenço Velho, coincidente com uma zona de cisalhamento précambriana reativada (Fig. 8). A presença conspícua de superfícies estriadas (espelhos de falha) e brechas tectônicas em todo o Planalto do Juqueriquerê e regiões adjacentes (com maior expressão ao longo da Falha do Camburu) sugere origem por abatimento tectônico, com idade mais recente que a intrusão de diques datados em $120 \mathrm{Ma}$ (Coutinho et al. 1992), também falhados.

A análise estatística das orientações de estrias e planos de falha revelou padrão indicativo de distensão tectônica na direção SE-NW, coerente com hipótese de abatimento tectônico do Planalto do Juqueriquerê por um sistema de falhas normais ENE. Essa direção esteve ativa no Cretáceo Inferior, associada à abertura do Atlântico Sul, quando houve a intrusão de centenas de diques básicos na região, bem como no Paleogeno, durante o desenvolvimento do sistema de rifts.

O caimento dos planaltos, conforme denotado pelo sentido de escoamento da rede de drenagem, mostra tendência para NW, no caso do Planalto do Moraes, e, para NE, nos planaltos do Lourenço Velho e do Juqueriquerê. Esta situação também sugere que o Planalto do Juqueriquerê tenha se originado por abatimento do Planalto do Moraes. 


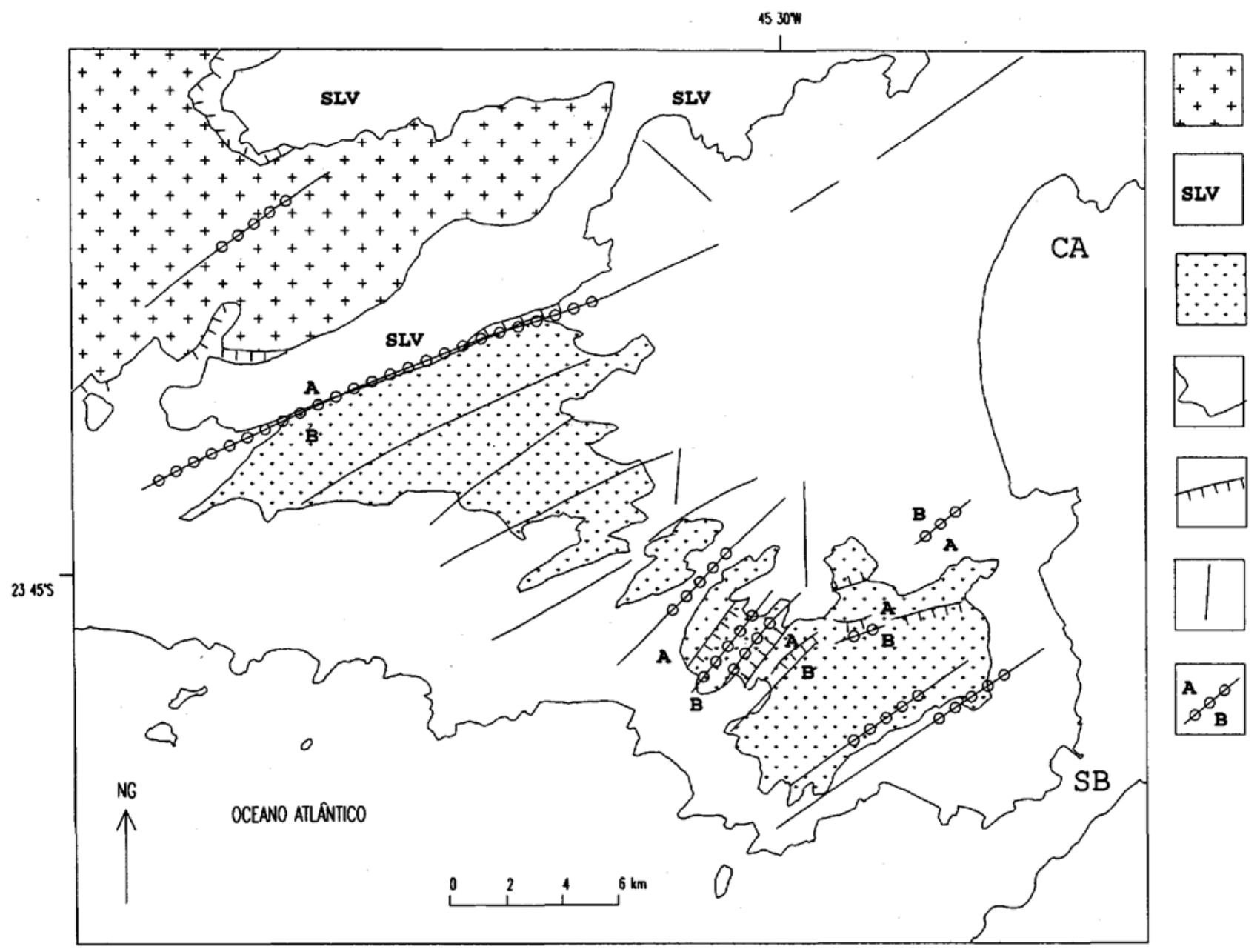

Figura 8 -Mapa morfotectônico do Planalto do Juqueriquerê e áreas adjacentes: (1) Planalto do Moraes; (2) Planalto do Lourenço Velho; (3) Planalto do Juqueriquerê,; (4) limite entre planaltos; (5) limite superior de escarpa entre planaltos; (6) fotolineamento; (7) falha de reativação com brechas, com indicação para bloco alto e baixo; (CA) Caraguatatuba; (SB) São Sebastião

Figure 8 - Morphotectonic map of the Juqueriquerê plateau and adjacent areas: (1) Moraes Plateau; (2) Lourenço Velho Plateau; (3) Juqueriquerê Plateau; (4) plateau limits; (5) upper limit of escarpment between plateau; (6) photolineament; (7) reactivation fault with breccias, with indication for up (A) and down (B) blocks; (CA) Caraguatatuba; (SB) São Sebastião

Uma origem tectônica para o Planalto do Juqueriquerê explica também o modelado do relevo que ele apresenta na região compreendida entre Boiçucanga, Maresias e a Serra do Dom. Nessa região, o Planalto do Juqueriquerê apresenta-se entalhado pelos Rios Maresias, Grande e Pirassununga, desmembrando-se em diversos patamares desnivelados. Esses patamares, dos quais o mais alto é a Serra do Dom, apresentam limites retilíneos entre si, onde foram encontradas falhas com brechas associadas.

Certamente, o abatimento tectônico do Planalto do Juqueriquerê não se deu na forma de um único bloco, mas sim na forma de blocos menores e zonas de largura variada apresentando diversas pequenas falhas, que, em seu conjunto, propiciaram o desnivelamento de 200 a $300 \mathrm{~m}$. Entretanto, ocorreu um movimento diferencial maior ao longo da Falha do Camburu, junto à qual, além de maior desnível topográfico, notam-se brechas cataclásticas mais expressivas, com estrias de atrito denotando movimentação do tipo normal.

Sobre as idades dos planaltos, a ausência de depósitos sedimentares expressivos associados às superfícies morfológicas analisadas inviabiliza os métodos usuais de datação utilizados nos estudos de evolução cenozóica. Tentou-se, então, alternativamente, a correlação das superfícies morfológicas aqui reconhecidas como superfícies de discordância expressivas no registro sedimentar das Bacias de Santos e Campos.

Nesse sentido, cabe considerar, inicialmente, que todas as observações indicam relação erosiva entre os Planaltos do Moraes e do Lourenço Velho, de tal sorte que é possível atribuir idade relativa mais antiga ao primeiro.

Assim, o Planalto do Moraes estaria nivelado pela mais antiga superfície erosiva da região, aqui correlacionada com discordância no registro sedimentar das Bacias de Santos e Campos, correspondente ao topo do Cretáceo, que vem sendo correlacionada por Macedo (1990) e Dias et al. (1990) com a Superficie Japi (Almeida 1964,1976), de idade paleogênica. A superfície mais nova, do Lourenço Velho, poderia também ter seu correspondente na Bacia de Santos, onde ocorre importante discordância no Mioceno Médio (Macedo 1990).

Por outro lado, nas Bacias de Campos e Santos há registro de atividade tectônica no Eoceno e no Mioceno Superior, esta última evidente nos perfis sísmicos da Bacia de Campos, promovendo deslocamentos verticais de até $300 \mathrm{~m}$ do topo do Mioceno (Dias et al. 1990). Na bacia de Santos, este tectonismo acha-se registrado na forma de abundantes leques proximais relacionados a rejuvenescimento da Serra do Mar. 
Em decorrência, admitindo-se idade miocênica média para o Planalto do Lourenço Velho, torna-se plausível admitir que abatimento do Planalto do Juqueriquerê tenha-se produzido durante os eventos tectônicos do Mioceno Superior.

Os eventos tectônicos aqui inferidos são razoavelmente concordantes com aqueles propostos por Almeida (1976), Riccomini (1989) e por Melo (1990) para as bacias sedimentares dos rifts continentais, com discrepâncias menores no tocante às idades e ao regime tectônico vigente. O evento eocênico de extensão é comum a todas proposições, sendo provavelmente equivalente à fase oligocênica de Almeida (1976). O evento miocênico, aqui considerado como responsável pelo abatimento do Planalto do Juqueriquerê, corresponde a uma fase transcorrente sinistrai de Riccomini (1989), a uma fase trativa E/W de Melo (1990) e a uma fase pliocênica de Almeida (1976).

Surge, assim, um modelo de evolução morfotectônica com os seguintes eventos principais: 1 . desenvolvimento da superfície erosiva do Planalto do Moraes entre o Cretáceo Superior e o início do Terciário; 2 . soerguimento crustal e desenvolvimento de nova superfície erosiva, no caso a superfície do Planalto do Lourenço Velho, durante o Mioceno Médio, preservando-se restos do Planalto do Moraes nas cabeceiras do Tietê e nas maiores elevações da Ilha de São Sebastião; 3. abatimento parcial da superfície do Planalto do Lourenço Velho no Mioceno Superior, originando o Planalto do Juqueriquerê.

As direções estruturais reativadas observadas na região remontam ao Pré-Cambriano, tendo sido reativadas no Cretáceo Inferior, e posteriormente no Eoceno e Mioceno Superior. Os sismos ainda hoje aí observados podem ser as últimas manifestações dessa tectônica recorrente.

CONCLUSÕES 1. Na região estudada, foram identificados três setores de planaltos, subnivelados em diferentes cotas altimétricas. Os dois mais elevados são aqui denominados Moraes e Lourenço Velho; o terceiro corresponde ao
Planalto do Juqueriquerê. Tais planaltos atingem as planícies costeiras através de escarpas acentuadas.

2.O Planalto do Juqueriquerê apresenta limite marcadamente retilíneo com relação ao Lourenço Velho, coincidente com uma zona de cisalhamento pré-cambriana reativada (a Falha do Camburu). A presença conspícua de superfícies estriadas (espelhos de falha) e brechas tectônicas em todo o Planalto do Juqueriquerê e regiões adjacentes, indicam abatimento tectônico dessa feição de relevo.

3.A análise estatística das orientações de estrias e planos de falha revelou padrão indicativo de distensão tectônica na direção SE-NW, coerente com a hipótese de abatimento tectônico acima enunciada, através de um sistema de falhas normais ENE. Essa direção esteve ativa no Cretáceo Inferior, associada à abertura do Atlântico Sul, por ocasião da intrusão de numerosos diques básicos na região.

4.A evolução morfotectônica mais provável para a área aqui enfocada envolve os seguintes passos: a. desenvolvimento da superfície erosiva correspondente ao Planalto do Moraes, entre o Cretáceo Superior e o início do Terciário; b. soerguimento crustal e desenvolvimento de nova superfície erosiva, correspondente ao Planalto do Lourenço Velho, provavelmente no Mioceno Médio; c. abatimento parcial do Planalto do Lourenço Velho no Mioceno Superior, originando o Planalto do Juqueriquerê; d. atenuação dos processos tectônicos, atualmente manifestos através da sismicidade característica da região.

Agradecimentos Os autores agradecem aos Professores Doutores Fernando F.M. Almeida, José M.V. Coutinho e ao colega geólogo Lauro K. Dehira, pelo apoio dado a este trabalho, bem como pelas discussões e sugestões dados no campo e no escritório. Agradecem ao Prof. Dr. Allaoua Saadi pela minuciosa revisão, críticas e sugestões à primeira versão apresentada. Agradecem também ao IPT e à Finep, bem como ao CEBIMAR (Centro de Biologia Marinha da USP), pelo apoio financeiro e operacional fornecido.

\section{REFERÊNCIAS BIBLIOGRÁFICAS}

ALEKSANDROWSKI, P. 1985. Graphical determination of principal stress directions for slickenside lineation populations: an attempt to modify Arthaud's method./ Struct. Geol, 7(1):73-82.

ALMEIDA, F.F.M. 1964. Fundamentos geológicos do relevo paulista. Boi Inst. Geogr. Geol., 41:169-263.

ALMEIDA, F.F.M. 1976. The system of continental rifts bordering the Santos Basin, Brazil. An. Acad. bras. Ci., 48(supl.):15-26.

ALMEIDA, F.F.M.; HASUI, Y.; PONCANO, W.L.; DANTAS, A.S.L.; CARNEIRO, C.D.R.; MELO, M.S.; BISTRICHI, C.A. 1981. Mapa Geológico do Estado de São Paulo. 1:500.000. São Paulo, IPT .v. 1, $126 \mathrm{p}$. (Monografias 6).

AMARAL, G.; BUSHEE, J· CORDANI, UG. KAWASHITA, K. REYNOLDS, J.H. 1967. Potassium-argon ages of alcaline rocks from Southern Brazil. Geochim. Cosmochim. Acta, 31:117-142.

ARTHAUD, F. 1969. Méthode de determination graphique des directions de raccourcissement, d'allongement et intermédiaire d'une population de failles. Bull. Soe. Géol. Fr. 11(7):729-737.

ASMUS, H.E. \& FERRARI, A.L. 1978. Hipótese sobre a causando tectonismo cenozóico na região sudeste do Brasil. In: PETROBRÁS. Aspectos Estruturais da Margem Continental Leste e Sudeste do Brasil. Rio de Janeiro, PETROBBRÁS/CENPES/DINTEP. p. 75-88. (Série Projeto REMAC 4)

BIGARELLA, J.J. \& AB'SABER, A.N. 1964. Palãogeographische und palãoklimatische Aspekte des Kãnozoikums in Südostbrasilien. Zeitschrift für Geomorphologie, 8(3):286-312.

BIGARELLA, J.J. \& ANDRADE, 1965. Contribution to the study of the Brazilian Quaternary. In: International Studies on the Quaternary. Geol. Soc. Am. Spec. Paper, 84:333-451

CAMPANHA, G.A.C.; RICCOMINI, C.; MELO, M.S.; HASUI, Y; ALMEIDA, F.F.M.; DEHIRA, L.K. 1985. Análise do padrão de fraturamento mesozóico-cenozóico de bacias tafrogênicas continentais do Sudeste do Brasil. In: SIMP. REG. GEOL., 5. São Paulo, 1985. Atas... São Paulo, SBG. v. 1, p. 337-350.
CAMPANHA, G.A.C. \& ENS, H.H. 1992. Análise Morfotectônica Integrada do Sudeste Brasileiro, Area do Planalto do Juqueriquerê. São Paulo IPT. 42 p. (Relatório Inédito 29991)

CAMPANHA, G.A.C.; ENS, H.H.; PONÇANO, W.L. 1992. Análise morfotectônica do planalto do Juqueriquerê. In: CONOR. BRAS. GEOL., 37. São Paulo, 1992. Boletim de Resumos Expandidos... São Paulo, SBG. p. 605.

CAMPANHA, G.A.C. \& ENS, H.H. 1993. Estrutura geológica na região de São Sebastião. In: SIMP. GEOL. SUDESTE, 3. Boletim de Resumos... Rio de Janeiro, SBG. p. 51-52.

CAMPOS NETO, M.C. \& FIGUEIREDO, M.C.H. 1992. A orogênese Rio Doce. In: CONOR. BRAS. GEOL., 37. São Paulo, 1992. Boletim de Resumos Expandidos... São Paulo, SBG. v. 1, p. 276-277.

COUTINHO, J.M.V.; ENS, H.H.; RODRIGUES, E.P.; TASSINARI, C.C.G. 1991. Mafic dyke swarms in the northern coast of São Paulo, Brazil (a preliminary report). In: INTERN. SYMP. MAFIC DYKES. São Paulo, 1991. Extended Abstracts... São Paulo, SBGq/Soc. Geol. Portugal, p.111-115.

COUTINHO, J.M.V.; ENS, H.H.; RODRIGUES, E.P. 1992. Petrography and field features of precambrian and mesozoic mafic dykes in southeastern Brazil. In: INTERN. GEOL. CONOR., 29. Kyotu, Japan, 1992. Extended Abstracts... Kyotu, Japan. $567 \mathrm{p}$.

CRUZ, O. 1974. A Serra do Mar e o Litoral na Área de Caraguataíuba Contribuicão a Geomorfologia Litorânea e Tropical. São Paulo, IGEOG/USP. 181 p. (Série Teses e Monografias 11).

DIAS, J.L.; SCARTON, J.C.; GUARDADO, L.R.; ESTEVES, F.R.; CARMINATTI, M. 1990. Aspectos da evolução tectono-sedimentar e a ocorrência de hidrocarbonetos na Bacia de Campos. In: GABAGLIA, .P.R. \& MILANI, E.J (coord). Origem e Evolução de Bacias Sedimentares. Rio de Janeiro, Petrobrás. p. 333-360.

FREITAS, R.O. 1947. Geologia e petrologia da Ilha de São Sebastião. Boi. FFLCH/USP, 85:1-244. (Geologia 3). 
FREITAS, R.O. 1951. Relevos policíclicos na tectônica do Escudo Brasileiro. Boi. Paul. Geog., (7):3-19.

FÚLFARO, V.J.; SUGUIO, K; PONCANO, W.L. 1974. A gênese das planícies costeiras paulistas. In: CONOR. BRAS. GEOL., 28. Porto Alegre, 1974. Anais... Porto Alegre, SBG. v. 3, p. 37-42.

FURTADO, V. V. 1978. Contribuição ao Estudo da Sedimentação Atual no Canal de São Sebastião do Estado de São Paulo. São Paulo. 92 p.

(Tese de Doutoramento, IG/USP)

HENNIES, W.T. \& HASUI, Y. 1968. Geocronologia das rochas eruptivas da Ilha de São Sebastião, SP. In: CONOR. BRAS. GEOL., 22. Belo Horizonte, 1968. Anais... Belo Horizonte, SBG. p. 145-148.

KING, L.C. 1956. A geomorfologia do Brasil Oriental. Rev. Bras. Geog. 18(2): 147-265.

MACEDO, J.M. 1990. Evolução Tectônica da Bacia de Santos e áreas continentais adjacentes. In: GABAGLIA, G.P.R. \& MILANI, EJ (coord). Origem e Evolução de Bacias Sedimentares. Rio de Janeiro, PETROBRAS. p. 361-376.

MACEDO, J.M.; BACOCCOLI, G.; GAMBOA, L.A.P. 1991. O tectonismo meso-cenozóico da região sudeste. In: SIMP. GEOL. SUDESTE, 2. São Paulo, 1991. Atas... São Paulo, SBG p. 429-438.

MARRET. R. \& ALLMENDINGER, R.W. 1990. Kinematic analysis of fault-slip data. J. Struct. Geol, 12(8):973-986.

MELO, M.S. \& PIRES NETO, A.G. 1977. Esboço geológico da província costeira entre as Serras do Juqueriquerê e Parati, Estado de São Paulo. In: SIMP. BRAS. GEOL., 1. São Paulo, 1977. Atas... São Paulo, SBG. p. 303-323.

MELO, M.S.; RICCOMINI, C.; HASUI, Y.; ALMEIDA, F.F.M.; COIMBRA, A.M. 1985. Geologia e evoluçã̃o do sistema de bacias tafrogênicas continentais do sudeste do Brasil. Rev. Bras. Geoc., 15(3):193-201.

MELO, M.S. 1990. A Formação Pariqüera Açu e Depósitos Relacionados: Sedimentação, Tectônica e Geomorfogênese. São Paulo. 211 p. (Dissertação de Mestrado, IG/USP).
PONCCANO, W.L.; CARNEIRO, C.D.R.; BISTRICHI, C.A.; ALMEIDA, F.F.M.; PRANDINI, F.L. 1981. Mapa Geomorfológico do Estado de São Paulo. São Paulo, IPT. v. 1. (Monografias 5).

PONÇANO, W.L. \& ALMEIDA, F.F.M. 1993. Superfícies erosivas nos planaltos cristalinos do leste paulista e adjacências: uma revisão. $\mathrm{Ca}$ dernos IG/UNICAMP, 3(1):55-90.

RAMSAY, J.G. 1967. Folding and Fracturing of Rocks. New York, McGraw-Hill. 568 p.

RICCOMINI, C. 1989.0 Rift Continental do Sudeste do Brasil. São Paulo. 256 p. (Tese de Doutoramento, IG-USP).

RUELLAN, F. 1944. Evolução geomorfológica da bacia de Guanabara e das regiões vizinhas. Rev. Bras. Geog., (4):445-508.

SALVADOR, E.D. 1994. Análise Neotectônica da Região do Vale do Rio Paraíba do Sul Compreendida entre Cruzeiro (SP) e Itatiaia (RJ). São Paulo. 129 p. (Dissertação de Mestrado, IG-USP).

SILVA, A.T.S.F. et al. 1977 O Complexo Bairro do Marisco (Caraguatatuba, SP). In: SIMP. GEOL, REG., 1. São Paulo, 1977. Atas... São Paulo, SBG. p. 74-90.

SOUZA, C.R.G. 1990. Considerações sobre os Processos Sedimentares Quaternários e Atuais na Região de Caraguatatuba, Litoral Norte do Estado de São Paulo. São Paulo. 334 p. (Dissertação de Mestrado, IO-USP).

SUGUIO, K. \& MARTIN, L. 1978. Mapas Geológicos das Planícies Costeiras Quaternárias do Estado de São Paulo e sul do Rio de Janeiro (1:100.000); Folhas Bertioga e Caraguatatuba. São Paulo, PAEE/SMA.

ZALÁN, P.V. 1986. A tectônica transcorrente na exploração de petróleo: uma revisão. Rev. Bras. Geoc. 16(3):245-257.

MANUSCRITO A810 Recebido em 11 de abril de 1994 Revisão do autor em 6 de janeiro de 1995 Revisão aceita em 5 de abril de 1995 